\title{
DESPUÉS DE BRECHT: EL TEATRO DE EDWARD BOND
}

\author{
SUSANA N. ROMÁN \\ Universidad de Almería
}

\section{RESUMEN}

El teatro épico de Brecht ha constituido una de las mayores influencias en el teatro contemporáneo inglés. Este artículo examina las técnicas teatrales de Brecht en el dramaturgo inglés Edward Bond y realiza un recorrido por los aspectos ideológicos y metodológicos de ambos autores para mostrar sus coincidencias y diferencias en conceptos como la historia, la psicología, la conexión de las escenas, la violencia como instrumento de cambio en la sociedad, las técnicas fundamentales del teatro épico, la música, la utilización de posters y el uso de las emociones.

Tras este recorrido, se concluye que a pesar de las evidentes huellas brechtianas en Bond, su teatro épico es diferente, pues no encuentra utilidad en el encumbramiento de Brecht. Nos dice Bond que nada es intemporal y que el teatro épico aún no ha sido elaborado en su totalidad.

Palabras clave: Teatro épico, Brecht, Bond, cambio social

\begin{abstract}
Brechtian epic theatre is one of the greatest influences in modern British drama. This article examines the development of Brecht's theatre techniques in the English playwright Edward Bond and proposes a general overview of the ideological and methodological aspects of both authors. This study tries to show their similarities and differences in concepts such as history, psychology, scene linking, violence as an instrument to change society, fundamental techniques of epic theatre, music, the use of posters and emotions.

After this general overview, the conclusion is that, despite the evident Brechtian traces in Bond, his epic theatre is different because it is based on the need to go beyond Brecht. Bond tells us that nothing is eternal and that epic theatre has not been totally developed.
\end{abstract}

Key words: Epic theatre, Brecht, Bond, social change. 
El uso que de la historia hace Edward Bond en sus obras pretende una interpretación del presente y el arma de cambio para el futuro, como señala Klein (1995: 409) en una entrevista personal con Bond: "The author has always pointed to the need to understand and to interpret rationally our past in order to use the experiences in our present and not to repeat the mistakes committed". Esta utilización del pasado en el presente encuentra su instrumento de transmisión en el teatro épico: "The form of the new drama will be epic" (Bond, 1992: 108). Como Brecht, Bond defiende la necesidad de un teatro épico, un análisis de la verdad que nos muestre la historia real de la humanidad desprovista de mitología y manipulación. Este tipo de teatro es un teatro racional que busca el análisis de las causas, como explica Klein (1989: 91):

Bond's epic theatre, in its conjunction of poetry and reason, is a rational form of theatre and has a pragmatic intention. He invites the audience to analyse and to change the dehumanizing structures of modern society by making them aware of their own oppression and alienation, and encouraging them to create a new consciousness through a rational understanding of the past.

Este teatro encuentra su esencia "in the way it selects, connects and judges" y, como señala Roberts (1981: 463), su punto principal reside en "the broad structure of history. It gives meaning to individual lives by placing those lives clearly in the context of what has determined the quality of those lives".

Holland (1978: 27) atribuye la influencia de Brecht sobre Bond de una manera indirecta a través de William Gaskill ${ }^{1}$ y del Royal Court. Sin embargo, el propio Bond corrigió a Holland: "I didn't get my 'Brechtianism' from the Court but from seeing the Berliner Ensemble in London in the late fifties. They were speaking a foreign language and I had no theatrical education, but I recognized his importance then as I'd only done with one other writer, Shakespeare (Bond, 1978: 35).

Al comprobar sus opiniones sobre el dramaturgo alemán a lo largo de su carrera, observamos que Bond ha evolucionado desde una negación absoluta de su influencia brechtiana hasta su reconocimiento. En 1970 declaró en una entrevista: "I don't think I'm influenced by Brecht at all" (citado en Holland, 1978: 27), mientras que treinta años después reconoce: "You know that I regard Brecht as an influence and of course I shall continue to be influenced by him" (Bond, 2000: 171). A pesar de no reconocer su deuda a Brecht en sus primeras obras, Bond (1972:13) demuestra su admiración, aunque considera que sus obras son demasiado inocentes: "I rather admire Brecht actually. I think his naivety covers painful knowledge".

Innes (1982: 196) argumenta que es precisamente este "painful knowledge" lo que comparten Bond y Brecht, además del mismo punto de partida filosófico. Ambos defienden que el ser humano está condicionado por la sociedad y que la condición de bondad o maldad viene impuesta por un sistema explotador de clases. Las diferencias históricas entre las clases sociales deben estar reflejadas en la obra teatral para no dar un sentido de igualdad contemporánea inexistente: "we must drop our habit of taking the different

\footnotetext{
${ }^{1}$ William Gaskill fue director de un grupo de creación de jóvenes escritores entre los que se encontraba Bond.
} 
social structures of past periods [...] so that they all look more or less like our own" (Willet, 1964: 190). Este interés por reflejar las diferencias entre las clases sociales persigue demostrar en escena las contradicciones de la realidad social en un sistema capitalista.

Bond defiende en "Types of Drama" la necesidad de un teatro épico que permita un análisis histórico y sus soluciones: "the play's figures and incidents would embody and demonstrate the total historical movement. [...] Incidents would be chosen to show how historical problems arise and how they lead to resolutions" (The Activists Papers, 1992: 129). Brecht también concebía el teatro épico como la única posibilidad de presentar la complejidad humana "in an age in which the life of individuals could no longer be understood in isolation from the powerful trend of social, economical, or historical forces affecting the lives of millions" (Esslin, 1984: 116).

La historia que se desarrolla en el teatro épico se convierte en fundamental, eliminando así la supremacía de los personajes por la de las relaciones humanas en la sociedad. El análisis psicológico de los personajes es irrelevante para Bond y para Brecht porque "the story [...] is the sequence of events which constitutes the social experiment of the play; it provides the dialectical field for the interplay of social forces, from which the lesson of the play will be seen to emerge" (Esslin, 1984: 123). Siguiendo esta línea, Bond defiende en sus cartas la importancia de la historia: "The story is there to show how the characters learn about themselves, how they acquire the abilities to understand their situation and gain power over it" (Stuart, 1995: 72), convirtiendo a estas historias comunes en la esencia del drama épico.

Una de las principales diferencias entre Bond y Brecht consiste en la conexión de las escenas. Brecht sugiere que cada escena puede ser completa en sí misma y que cada una puede ser utilizada para representar la realidad, mientras que Bond considera esencial la relación causa-efecto entre las escenas como parte del análisis. Bond defiende así la unidad en el teatro épico: "The epic's structure must have meaning- it is not a collection of scenes showing that meaning is logically possible. The epic must have a unity based on practical truth, just as once it was based on mythological coherence. This unity comes from the analysis, which demonstrates, embodies cause and effect in a coherent way." (Bond, 1996: 136)

Para Bond (1978: 35), esta relación causa-efecto es un reflejo de la vida y por tanto, condicionante fundamental en su representación de la realidad: "life is ordered by cause and effect, incident and choice, problem and decision and this reality must be reflected in the structure of the play". Holland (1978: 31) observa que Bond ofrece percepciones interconectadas del mundo desde una perspectiva social y moral, siendo la escena "the presentation of a moment of society (not of character), and is defined as a segment- not in the terms of the diachronicity of play-time, but of its synchronic views of real-time". Bond deforma así la estructura tradicional de división temporal, situando en su lugar las divisiones en el argumento de acuerdo con la intensidad emocional que pretenda aplicar. Esta concepción diferente de las escenas también se refleja en el sentido de urgencia que Bond imprime en sus obras, "the urgency of the time in a world poised to destroy itself" (Roberts, 1981: 459). Esta necesidad hace que Bond utilice al contrario que Brecht "short, even fragmented scenes to gain intensity, and starkly powerful images for emotional immediacy" (Innes, 1982: 197). 
Para Bond (1996: 136), el significado se encuentra en la dramatización del análisis que se convierte así en el cometido principal del público "when the audience are asked to be not passive victims or witnesses, but interpreters of experience, agents of the future, restoring meaning to action by recreating self-consciousness". Brecht ya había definido al espectador del teatro épico como agente del cambio, oponiéndolo al pasivo espectador del teatro dramático: "The epic's theatre spectator says: [...] That's not the way [...]. It's got to stop -the sufferings of this man appal me, because they are unnecessary" (Willett, 1964: 71).

Ambos autores demandan, pues, la necesidad de un cambio en la sociedad y hablan de la violencia como instrumento de cambio. Esslin (1984) habla de una postura ambigua de Brecht frente a la necesidad de la violencia en el cambio social ya que por un lado afirma que es necesaria: "The victory of reason could, for him, only be brought about by violent means" (228) y por otro, defiende la no violencia para una victoria de la revolución: "[...] the movement of the softest water will / Conquer in time the powerful hard stone. / You understand: hard things are overcome..." (243). Bond (1997: 17) tiene claro en On Violence que la violencia de nuestro mundo procede del sistema injusto en el que vivimos y que bajo el capitalismo no es posible la paz. Justifica, por tanto, la violencia de la izquierda como único medio de lucha en una sociedad irracional en la que la razón ya no es efectiva:

I am not a pacifist, we have to say what things are and not what we would like them to be. Reason is not yet always effective, and we are still at a stage when to create a rational society we may sometimes have to use irrational means. Right-wing political violence cannot be justified because it always serves irrationality; but left-wing political violence is justified when it helps to create a more rational society, and when that help cannot be given in a pacific form (la cursiva es mía).

Bond ha sido muy criticado por estas opiniones pero es necesario señalar que la mayor parte de sus ensayos critican la violencia y como apunta Klein (1995: 176): “only if no pacific solution is possible to alleviate the situation of injustice, only then does he propose to turn to violent action to counteract the organised and controlled violence of the establishment".

Spencer (1992) explica muchos aspectos en los que Bond y Brecht coinciden, como su visión de la realidad como histórica y sujeta a la intervención humana susceptible de cambio, la relación entre historia e individuo y su rechazo de la ideología como mediadora en la experiencia de la realidad. Sin embargo, encuentra una diferencia fundamental entre ambos autores en los distintos ritmos y referencias, defendiendo la mayor riqueza de géneros del dramaturgo inglés. Brecht pensaba que la sociedad irremediablemente se encaminaba al socialismo, mientras que "Bond shares with most latter-day Marxists the belief that history does not move automatically toward socialism or any other predetermined end" (Spencer, 1992: 7). Podemos decir que ambos buscaban inspirar en su audiencia el cambio social, pero Bond va un paso más allá y ya no se pregunta “ 'how' change will occur [...], but who will do the changing?" (108).

En cuanto a la utilización de Bond de técnicas específicamente brechtianas, las parábolas constituyen un referente fundamental sobre todo en The War Plays. Reinelt (1994: 
54) entiende que una parábola "sets out a particular model of the world, usually Utopian or dystopian, in order to construct a parallel between the posited world and our own". La parábola, para Bond y Brecht, no proporciona conocimiento directamente sino que utiliza la historia como método de aprendizaje desde un distanciamiento de la realidad. Spencer (1992: 110) explica las ventajas que suponía la técnica de la parábola para Bond y Brecht: "its history of instructional use, its connection with religious literature, and its tendency toward self-explication".

Otro de los recursos fundamentales brechtianos en Bond es la utilización del "not...but" a partir de la obra The Bundle (1978). La problemática entre la opción de Bien y Mal en situaciones de injusticia presenta su análogo en Brecht, según Spencer (1992: 122), "in the imposssible or unnatural decision mandated by an inhuman social system". El elemento brechtiano "Not-But" se encuentra en relación con esta doble problemática en la que cada decisión presenta una alternativa y en la que se observa la presión ejercida por la cultura dominante sobre el ser humano:

[...] that is to say he will act in such a way that the alternative emerges as clearly as possible, that his action allows the other possibilities to be inferred and only represents one out of the possible variants. [...] In this way every sentence and every gesture signifies a decision; the character remains under observation and is tested. The technical term for this procedure is "fixing the "not...but"' (Willet, 1964: 137).

Otra de las técnicas fundamentales del teatro épico de Brecht es el establecimiento del "gestus" que permite cambiar el énfasis "from the inner life of characters towards the way in which they behave towards each other" (Esslin, 1984: 124). Spencer (1992) señala cómo el gesto de Brecht permanece en la memoria del espectador centrando su atención en la conexión de las relaciones sociales y sus contradicciones, siendo este sentido de "iluminación" el que Bond utiliza para sus obras. El contenido del gesto social tiene como objetivo presentar en escena la relación social en términos económicos y Bond la reutiliza en términos políticos: "He always historicizes the incidents of the narrative, providing a representation of the social construction of the subject, in scenes with a clear political gestus" (Reinelt, 1994: 51). Holland (1978: 28) demuestra que la estructura dramática de Bond procede del "gestus" de Brecht al utilizar los objetos como la base "for the analysis of the social existence of the individual".

La música también es un elemento considerado gestual en el sentido brechtiano. Los números musicales, según Esslin (1984: 118), "are introduced as entirely distinct ingredients of the play, which interrupt its flow, break the illusion, and thereby render the action 'strange"'. Desuché (1968) entiende que la música brechtiana es autónoma en relación al texto convirtiéndose a menudo en su negación pero estas contradicciones siempre tendrán un sentido social y político más que puramente estético. La función de la música no es afectiva "sino que suscita el despertar de la inteligencia, porque fustiga; en un momento dado, detona y, sin embargo, permanece en secreto acuerdo con aquello que los actores dicen" (Desuché, 1968: 64). Sin embargo, aunque Bond utiliza canciones en muchas de sus obras, especialmente Restoration, no está de acuerdo con la concepción musical de Brecht. Defiende que la música no puede ser alienada, no tiene significado, no miente ni 
dice la verdad: "Brecht uses music in the way Wagner uses myth. Both are external authorities" (Bond, 1998: 326). Bond utiliza la música como elemento transgresor y no como mero transmisor de lecciones socialistas al modo brechtiano. Worth (1981: 483) ve en la música utilizada por Bond en Restoration un toque de revolución al incluir música rock en el ambiente pastoral del siglo XIX que recrea la obra. Las canciones de los criados, con un sentido agresivo y dinámico, se convierten así en el único reducto de libertad en el que pueden soñar: "They gain the articulacy they lack in that world".

Bond tampoco coincide con Brecht en el uso de posters o pancartas sobre la escena. Y aunque considera que ayuda al espectador a entender lo que se muestra y contemplarlo desde una nueva perspectiva, cree, en su defensa absoluta de la racionalidad, que la presentación física de algo no demuestra que sea cierto. Sin embargo, la utilización de los coros es fundamental en las obras de Bond. Según Desuché (1968: 88), el coro es "un canto que no queda superpuesto en la obra, sino que es como su misma respiración íntima, aérea, como el murmullo de los protagonistas". El coro otorga a obras como The Mother un claro movimiento hacia delante, dice lo que piensa la gente, sin comentarios impersonales. Desuché (1968: 89) define el coro brechtiano, también recogido por Bond, como la forma de liberar "la moral de la obra, en este instante, y nos arranca del puro conocimiento psicológico de los personajes con hundimientos dentro de la historia: nos llama otra vez al centro del teatro". Para Bond, el coro no puede convertirse en el objetivo final sino en el medio para transmitir un mensaje. En una de sus cartas, se le preguntó a Bond si el coro "My Spain", de Human Cannon, podría ser representado por varias mujeres pero el autor rechazó esta idea por el carácter romántico que se le imprimiría: "Otherwise the chorus becomes a product and not a process" (Stuart, 1995: 74).

Ambos autores difieren inicialmente en uno de los elementos clave del teatro épico: el uso de las emociones para implicar a la audiencia. Esslin (1984: 19) encuentra en el teatro épico de Brecht "the rejection of empathy and the emotional involvement of the audience". Sin embargo, el dramaturgo alemán asegura que su teatro apela más a la razón del espectador que a sus sentimientos. Al principio, Brecht invitaba a la audiencia a distanciarse de la acción mediante el proceso de alienación, pero hacia el final de sus teorías prefirió aunar emoción y alienación en una propuesta más similar al teatro de Bond. Las emociones que pretende provocar Brecht van más allá del terror y la piedad como "the love of justice, the urge to freedom or justified anger”, según observa Esslin (1984: 130), defendiendo una base clasista que distingue entre ricos y pobres y un carácter temporal en las emociones: "The emotions are in no sense universally human and timeless" (Willett, 1964: 145). Bond habla de las emociones en este mismo sentido de productividad y no como una cualidad estática:

I read this morning a remark by a socialist that it was important to emotionally involve audiences in the play's action. This seems to be the opposite of Brecht's alienation. [...] We shouldn't think of emotions as operating "in a situation" or being needed to be "controlled" to achieve socialisation: they are productive of our situation and are produced by them. So emotions are cultural structures... (Stuart, 1995: 100-101). 
En su intención de implicar a la audiencia emocionalmente, Bond crea los "aggroeffects" que difieren de los "alienation effects" de Brecht, aunque ambos comparten una function didáctica: "In contrast to Brecht, I think it's necessary to disturb an audience emotionally, to involve them emotionally in my plays, so I've had to find ways of making that "aggro-effect" more complete, which is in a sense to surprise them" (citado en Innes, 1982: 199). Innes defiende así la violencia presente en las obras de Bond como "a measure of urgency" y la necesidad de presentar la obra teatral no como catarsis aristotélica sino "as a sort of shock therapy designed to galvanize their consciences into life and provoke them into viewing society "objectively" and "rationally"" (199). Rabey (1986: 114) también entiende que el uso de las emociones en el teatro de Bond como llamada de atención supone una ruptura fundamental con Brecht. Bond busca una respuesta efectiva en el espectador que sólo es posible por medio de imágenes duras y sorprendentes que obligan a la reflexión y la acción.

Bond (1978: 35) pretende desarrollar un "V-effect" menos abstracto que Brecht y más positivo: "if V-effect becomes merely the removing of emotional tension so that the object or situation being inspected just, as it were, floats loose". En sus últimas obras, Bond ha continuado desarrollando esta idea en lo que ha denominado Theatre Events (TEs). Spencer (1992: 227) defiende la ampliación del enfoque desde los iniciales "aggro-effects" hasta los TEs sugiriendo un cambio "in the text-actor-audience dynamic" pero aún se observan claras diferencias con los "A-effect" brechtianos a pesar de compartir un similar propósito político: "TEs explicitly promote audience analysis of a situation that presents itself onstage as unacceptable (violent), paradoxical (stranged), unbelievable (exaggerated, understated, or absurd), or ironic" (227). El propio Bond (1998: 325) en "Commentary of the War Plays" encuentra las bases de las diferencias entre los efectos brechtianos y los TEs en las teorías de la Ilustración:

TEs are not simple Brechtian alienation effects. [...] Yet alienation theory depends on a philosophy of mind held by Diderot and other eighteenth-century rationalists. It appeals to objective judgement but does not secure the means of achieving it. The mind cannot get outside itself to be objective. The structure of mind is part of the continuum of society.

Además de la base filosófica, los TEs difieren de los "A-effects" en cuanto a la autoridad que confieren al espectador. Reinelt (1994: 79) explica que en el teatro actual la audiencia se convierte en responsable de su propia autoridad: "in TEs the authority resides with the producers of that meaning, the triangle of participants and their work on the text(s)", mientras que Brecht apelaba a una autoridad externa. Bond también entiende que la alienación de Brecht es habitual en el teatro contemporáneo, por tanto, el reto es "to manipulate the metatext to make the audience the authority- to make them decide what the alienation is" (citado en Reinelt, 1994: 79). Su nueva concepción pretende ir más allá de la alienación de Brecht y reconoce en una de sus cartas que "what has to be alienated is not the stage but the audience" (Stuart, 1995: 187).

\footnotetext{
${ }^{2}$ Bond se refiere a los "alienation effects" de Brecht en algunas ocasiones como "V-effect", tomado del original alemán Verfremdungseffekt o en otras ocasiones como "A-effect".
} 
Por otro lado, además de los TEs, Bond ha desarrollado otras técnicas como el soliloquio público procedente del soliloquio shakesperiano. Klein (1989: 83) señala la importancia de estas nuevas estrategias dramáticas: "The communication tool of 'direct address' [...] is an effective device to arouse the audience's commitment to the political topics and social concerns of the play and to engage them more directly and analytically". Este uso de soliloquios similar a los monólogos y apartes del teatro isabelino "accentuates the epic character of his theatre" (83). Bond define el soliloquio público como un elemento esencial para la transmisión de la historia y la conciencia política: "He [the character] then talks not as he is but as he would be after we have been there. His age stays the same but he speaks with historical hindsight, with greater political consciousness and stronger political presence than he yet has. [...] It would be nearer the truth to say that the author becomes the spokesman of his character..." (Bond, 1992: 139-140)

Tras este recorrido por las coincidencias y diferencias entre ambos autores, podemos concluir que a pesar de las evidentes huellas brechtianas en la obra de Bond, el dramaturgo inglés desarrolla las nociones del teatro épico de una manera diferente, dotándolas de contemporaneidad. Reinelt (1994: 80) concluye que existe una reciprocidad entre ambos autores: "Edward Bond illuminates Brecht's work, just as Brecht helps to interpret Bond's", mientras que Spencer (1992: 4) atribuye a Bond las nuevas creaciones como alumno aventajado: "Bond's contribution to modern drama will lie in his development of a dialectical theatre along Brechtian lines [...] that addresses the most significant political issues of his time". Hirst (1985: 127) considera importante analizar los dramas épicos de Bond desde las teorías brechtianas pero reconoce que ambos autores han desarrollado el potencial político del teatro épico en momentos históricos diferentes. Sin embargo, las intenciones políticas de Bond son más extremas que las de Brecht y sus propuestas escénicas más arriesgadas: "if we observe similarities of method we must also realise that Bond inevitable goes further than Brecht in disturbing and challenging his audience".

Bond (1978: 35) ha desarrollado la teoría brechtiana, como él mismo ha reconocido, pero no todo puede quedar en Brecht: "Brecht is no more a writer for all time than Shakespeare is". El dramaturgo alemán perteneció a un momento histórico pasado en el que sus obras dependían de hechos muy concretos como el surgimiento del fascismo en Alemania pero Bond, en su generación de violencia y sin alternativas políticas, considera la aproximación teatral de Brecht pasada de moda. Bond no encuentra utilidad al encumbramiento de una figura, sea Brecht, Shakespeare o cualquier otro, ya que esto significaría que no hay nada más por hacer. Nada es intemporal, dice Bond (1978: 35), por tanto, el trabajo no ha concluido ya que el teatro épico aún no ha sido elaborado en su totalidad: "starting with Brecht but not ending there [...] the work is not yet finished".

\section{REFERENCIAS BIBLIOGRÁFICAS}

Bond, E. 1972. "Drama and Dialectics of Violence" Theatre Quarterly, 2, 5: 4-14

1977. Plays: 1. Saved. Early Morning. The Pope's Wedding. London: Methuen.

1978. “On Brecht: a Letter to Peter Holland”. Theatre Quarterly, 30: 34-35. 
1992. Plays: 4. The Worlds. The Activists Papers. Restoration. Summer. London: Methuen.

1996. Plays: 5. Human Cannon. The Bundle. Jackets. In the Company of Men. London: Methuen.

1998. Plays: 6. The War Plays. Choruses from After the Assassinations. London: Methuen.

2000. The Hidden Plot. Notes on Theatre and the State. London: Methuen.

Desuché, J. 1968. La técnica teatral de Bertolt Brecht. Barcelona: Tau.

EssLin, M. 1984. Brecht. A Choice of Evils. $4^{\text {th }}$ ed. London: Methuen.

HiRst, D.L. 1985. Edward Bond. Macmillan Modern Dramatists. London: Macmillan.

Holland, P. 1978. "Brecht, Bond, Gaskill, and the Practice of Political Theatre". Theatre Quarterly, 30: 24-34.

Hormigón, J. A. et al. 1975. Brecht y el realismo dialéctico. Comunicación Serie B 41. Madrid.

InNEs, C. 1982. "The Political Spectrum of Edward Bond: From Rationalism to Rhapsody”. Modern Drama, XXV, 2: 189- 206.

Klein, H. 1989. "Human Cannon- An Epic History Play by Edward Bond”. Anejos de Analecta Malacitana 6. Estudios de Filología Inglesa. Málaga: Universidad de Málaga: 81-91.

- 1995. "Edward Bond: An Interview". Modern Drama, 38: 4: 408- 415.

. 1995. "Violence in the Theatre of Edward Bond". In-between Essays \& Studies in Literary Criticism, 4: 2 (September 1995): 163- 179.

RABEY, D. I. 1986. British and Irish Political Drama in the Twentieth Century. London: Macmillan.

ReINELt, J. 1994. After Brecht. British Epic Theater. Ann Arbor: University of Michigan Press.

RoBerTs, P. 1981. “The search for epic drama: Edward Bond's recent work”. Modern Drama, 24: 458-478.

SPencer, J. S. 1992. Dramatic Strategies in the Plays of Edward Bond. Cambridge: Cambridge University Press.

StuART, I., ed. 1995. Edward Bond. Letters II. Luxembourg: Harwood.

Willett, J., ed. 1964. Brecht on Theatre. London: Methuen.

Worth, K. 1981. “Bond's Restoration”. Modern Drama, 24: 479- 493. 